\title{
A RELAÇÃO DOS ADOLESCENTES COM A ESCRITA EXTRACURRICULAR E ESCOLAR - INCLUSÃO E EXCLUSÃO POR VIA DA ESCRITA
}

\section{TEENAGERS' RELATIONSHIP WITH IN-SCHOOL AND EXTRA-SCHOOL WRITING - INCLUSION AND EXCLUSION THROUGH WRITING}

\author{
Inês Cardoso* \\ Luísa Álvares Pereira
}

\section{RESUMO}

Neste artigo, partimos de alguns apontamentos sobre o desenvolvimento do ensinoaprendizagem da escrita em Portugal, sintetizando diferentes enfoques investigativos. Assumiremos as dimensões cognitivas, pessoais e sociais da escrita e baseamo-nos no pressuposto de que deve estar subjacente ao processo de aprender e ensinar a escrever, numa perspetiva multifuncional e processual, o conhecimento sobre a relação dos alunos com a escrita, em contextos escolares e extraescolares.

Do dispositivo metodológico montado, centramo-nos numa oficina sobre a escrita com adolescentes e na descrição de dimensões que configuram a complexidade das suas relações com a escrita. Chegámos, assim, à conceptualização de três ideais-tipo de relação com a escrita, que se constituem em modos de interpretar este fenómeno pluridimensional e instável, e são suscetíveis de fornecer pistas para um ensino mais inclusivo da produção escrita, produzindo uma relação mais positiva dos alunos com este modo de expressão.

Palavras-chave: relação com a escrita; escrita extraescolar/livre; oficina sobre a escrita.

\section{ABSTRACT}

$\mathrm{n}$ this article, we will begin with some notes on the development of teaching/learning of writing in Portugal, synthesizing different investigative approaches. Assuming the cognitive, personal and social dimensions of the written language, we will argue that the knowledge about the relationship students (subjects) establish with writing, both in school and extra-school contexts, shall underlie the learning and teaching process of writing, on a multifunctional and processual perspective.

As far as the methodological device is concerned, we will focus on a workshop about writing with teenagers. The description of the dimensions which make up the complexity of the subjects' relationship with writing led us to the conceptualization of three ideal types of relationship with writing. These consist of different ways of interpreting this pluridimensional and

\footnotetext{
* York University, Toronto, Canadá, icardoso@yorku.ca _Universidade de Aveiro, Aveiro, Portugal, lpereira@ua.pt
} 
unstable phenomenon that may offer new pedagogical clues as to a teaching of writing that promotes a more favorable relationship with it.

Keywords: relationship with writing; extra-school writing; workshop about writing.

\section{RUMOS DA DIDÁTICA DA ESCRITA EM PORTUGAL: CONTEXTUALIZANDO A EMERGÊNCIA DA "RELAÇÃO PESSOAL COM A ESCRITA"}

À assunção da produção escrita como um complexo e poderoso instrumento à disposição do Homem estará associado o reconhecimento de que a escrita terá sido uma das mais significativas invenções da humanidade, a que um avanço civilizacional, cultural e científico expressivamente mais acelerado se terá ficado, em parte, a dever (GOODY, 1988). Talvez por esta razão à (competência de) escrita esteja associado um prestígio escolar e social que faz do saber escrever uma das prioridades do sistema educativo e, da escrita, um domínio omnipresente e central na escola.

A centralidade da escrita na escola e na sociedade atual, não sendo alheia ao facto de se reconhecer que a composição escrita é uma das atividades mais difíceis, exigentes e complexas que os seres humanos podem empreender, comporta exigências escriturais acentuadas, que vêm desnudar dificuldades relativas ao escrever, ao aprender a escrever e, logo, ao ensinar a escrever, para além de que aumenta a responsabilidade de quem ensina. A provar a complexidade da escrita, vários caminhos investigativos têm consolidado o seu contributo para uma ciência que os procura integrar de forma global - a Didática da Escrita (DE) (REUTER, 1996) - de forma a poder relevar que conhecimentos é preciso ter para (ensinar a) escrever e modos de ação didática que os integrem.

Deste lugar disciplinar, necessariamente poliédrico - e recente, entre nós -, tem sido possível constatar que a uma cultura que valoriza o escrito não têm correspondido meios de, em contexto escolar formal, promover a apropriação de uma produção textual multifuncional bem-sucedida (PEREIRA, CARDOSO, GRAÇA, 2009). Com efeito, o diagnóstico acerca do ensino e da aprendizagem da escrita, em Portugal, tem permitido realçar, com grande evidência, um ensino da escrita redutor bem como dificuldades significativas no domínio da produção escrita (AMOR, 2004; PEREIRA, ALEIXO, CARDOSO, GRAÇA, 2010).

Neste quadro, tem ganho relevo a urgência de inverter a tendência para a informação já disponível em DE tardar a produzir efeitos, sobretudo ao nível das práticas letivas. Assistimos, assim, à configuração de uma $\mathrm{DE}$, entre nós, que tem valorizado "três entradas", coincidentes com o conhecido "triângulo didático": 
i. pelo professor - começando pelas lógicas de funcionamento didático por parte de quem ensina (PEREIRA, 2004), para apontar caminhos coerentes para uma formação de professores para o ensino da escrita (PEREIRA, 2001a), problematizando o papel das ferramentas didáticas (GRAÇA, 2010) e o da própria escrita em dispositivos de formação para a escrita, particularmente a forma como os escritos da formação se podem constituir em instrumentos de desenvolvimento profissional para o ensino da escrita (PEREIRA, CARDOSO, 2010);

ii. pelos saberes - os textos a escrever - considerando, evidentemente, a escrita na sua natureza de atividade recursiva e, nesta linha, passando do enfoque no texto enquanto produto para um enfoque no processo de escrever texto. Releva, assim, a informação sobre os modelos processuais de escrita e de revisão textual (HAYES, 1996; CHANQUOY, 2009) bem como reflexões suscitadas pelas teorias do texto e modelos mais divulgados (ADAM, 2001; COUTINHO, 2003; BRONCKART, 2007), preferencialmente, no nosso grupo, a linha teórica do Interacionismo Sociodiscursivo (BRONCKART, 2005). Assim, consideramos os textos empíricos como a face mais visível de determinados géneros, entendendo estes como práticas sociais, históricas, adstritas a situações de uso da linguagem distintas, em diversas esferas de atividade humana (escolar, jornalística, jurídica, etc...) (SCHNEUWLY, DOLZ, 2004). O ensino em torno de géneros é, portanto, produtivo do ponto de vista do conhecimento que o aluno vai construindo sobre o funcionamento dos textos ${ }^{1}$ que circulam na esfera social e escolar, aproveitando a experiência sociotextual dos alunos e permitindo-lhes agir discursivamente numa situação de produção, isto é, produzir textos com a qualidade desejável e expectável em cada situação. A avaliação formativa e sumativa da qualidade dos textos assume-se, por conseguinte, no seu potencial de diagnóstico, de regulador de práticas e de aferição de resultados do trabalho de ensino dos textos;

iii. pelos alunos - reconhecendo a escrita como atividade movida por um mundo subjetivo, quer na escola quer em contextos pessoais, mas também

\footnotetext{
1 Sobre a matéria do funcionamento dos textos, consideramos contributos teóricos diferentes, mas complementares; por exemplo, as classificações de sequências textuais (ADAM, 2001) manifestam um caráter descritivo, apenas relativamente a questões linguísticas; são finitas e tentam categorizar a multiplicidade. Já os "géneros de texto" têm uma identidade própria, fruto de um conjunto de parâmetros definitórios, identidade ou especificidade essa que não se consegue apenas pela "soma" ou predominância de certos tipos de sequência textual: os géneros são por si infinitos e impossíveis de categorizar e tipologizar de forma tão fechada.
} 
profissionais, institucionais, o que se coaduna com as dimensões cognitivas e sociais da escrita que acabámos de destacar. $\mathrm{O}$ aluno, com a sua subjetiva forma de gerir o seu mundo subjetivo bem como o mundo objetivo e social, tem, então, um papel fundamental na apropriação de mecanismos para escrever eficiente e eficazmente; esta apropriação, por conseguinte, não será alheia à imagem de escrevente que vem configurando acerca de si mesmo e às representações que vai forjando acerca da escrita e do texto que escreve (PENLOUP, 2006); de facto, na linha da complexidade que a gestão do processo escritural comporta, "écrire et apprendre à écrire est beaucoup plus qu'une activité technique, c'est une activité qui engage toute la personne" (CHARTRAND, 2006, p. 84).

Digamos que estas "três entradas" se traduzem também em "duas saídas" principais em termos de "contextos privilegiados de intervenção/investigação/ formação", do que tem sido feito neste âmbito em Portugal, designadamente:

i. com efeitos para a aula de língua - a conceção, teste e validação de dispositivos de ensino de vários géneros textuais (PEREIRA, GRAÇA, 2008; PEREIRA, CARDOSO, 2011; PEREIRA, CARDOSO, 2013), que contemplem as diferentes etapas do processo escritural, acompanhadas do desenvolvimento da consciência metalinguística do Sujeito escrevente (BARBEIRO, 1999; BARBEIRO, PEREIRA, 2008) e da identificação de modos de trabalho fundados na facilitação do procedimento escritural (CARVALHO, 1999). Neste sentido, parte-se da premissa de que é necessário reforçar a atenção a uma fase crucial da escrita, a da aprendizagem da textualização, visto que as respetivas operações são indissociáveis da natureza específica do género do texto a produzir e do saber específico sobre esse género de texto, nele incluídas as próprias estruturas gramaticais a mobilizar (PEREIRA, 2008), bem como são indissociáveis da relação pessoal que o aluno vai estabelecendo com a escrita (CARDOSO, 2009). Procuramos, ainda, observar o modo como um uso criterioso das Tecnologias da Informação e da Comunicação (TIC) pode constituir um poderoso recurso ao serviço de uma metodologia renovada e consistente de ensino-aprendizagem da escrita (ROSÁRIO, 2010; CORTESÃO, 2012). Destes dispositivos de ensino, destacamos aquele que nos parece mais aglutinador das dimensões textuais/processuais, contextuais/sociais e pessoais da escrita que mencionámos, a sequência de ensino (PEREIRA, CARDOSO, 2013), a que reconhecemos um grande potencial 
formativo na medida em que os professores participam da sua definição, implementação e avaliação.

ii. com efeitos para a aula de língua, e para diferentes disciplinas - escrever para aprender - os estudos que se preocupam com as práticas de escrita em diferentes contextos disciplinares, do ensino superior e não superior, que têm demonstrado a especificidade de diferentes géneros escriturais escolares/ académicos e, portanto, a necessidade do seu ensino explícito (PINHO, 2008; RODRIGUES, 2010; CARVALHO, 2013).

Sejam quais forem os enfoques investigativos - nos textos (inseridos em contextos) ou nos Sujeitos (professores e alunos) -, nota-se, neste caminho, como tem sido prioritário contribuir para que a experiência de ensino e de aprendizagem da escrita seja produtiva para todos, sobretudo visando os "excluídos da escrita escolar" (PEREIRA, 2001b). O grande objetivo é permitir aos alunos a participação numa formação para a escrita que não os exclua das "lógicas escriturais", a começar pelas "lógicas da escrita escolar" (LAHIRE, 2008), mas que lhes faculte o acesso e a socialização em diferentes saberes disciplinares (BAUTIER, 2008). Ora, no nosso ponto de vista, e retomando a entrada "pelo aluno", o domínio das lógicas e práticas escriturais de que a escola começa por ser a guardiã não depende unicamente da aposta na vertente processual e cognitiva da escrita, mas também da consideração das dimensões pessoais e sociais que já referimos, nomeadamente, interessando-nos mais, neste texto, a adesão psicoafetiva do Sujeito à escrita e como essa adesão é marcada axiologicamente.

Por esta razão, um interesse assim dirigido ao Sujeito e ao quadro sociocultural em que se insere leva-nos a assumir a pertinência e a operacionalidade da inscrição do nosso trabalho numa corrente de investigação em DE que assenta sobre a noção de "rapport a" - a relação com o saber, em geral (CHARLOT, BAUTIER, ROCHEX, 1992; CHARLOT, 1997), e a relação com a escrita (BARRÉ-DE MINIAC, 2000), em particular. A nossa prioridade foi aceder, precisamente, à voz dos Sujeitos/alunos para descrever e interpretar a sua relação com a escrita e, concomitantemente, procurar intervir nessa relação.

Para melhor compreender o estudo que empreendemos, propomos, primeiramente, um enquadramento conceptual da problemática bem como uma breve descrição do dispositivo metodológico adotado. Finalmente, apresentaremos os resultados relevantes para o enfoque que aqui escolhemos e algumas considerações finais. 


\section{PARA UMA DIDÁTICA DA RELAÇÃO COM A ESCRITA}

Correndo o risco de usar um "lugar-comum pedagogicamente correto" (RAYOU, 2000), afirmaremos que os dispositivos de ensino e de aprendizagem da escrita, para serem completos e produtivos, não podem negligenciar o Sujeito/ aluno. Reconhecemos, contudo, a este pressuposto, alguma tendência para uma deriva que, em contexto escolar, pode produzir exatamente o efeito contrário: em vez de promover a inclusão, compactua com a exclusão, na medida em que deixa o aluno acomodar-se à sua linguagem de origem, sem a preocupação de, pelo menos, atenuar as desigualdades que marcam essas linguagens com que os alunos chegam à escola.

Seguindo um modelo de competência de escrita que não pressupõe apenas os "saberes" e as "técnicas", mas inclui as representações e motivações do Sujeito relativamente à escrita e ao escrever - que podem, até, estar a prejudicar a adesão à "causa da escrita" (escolar) -, cremos que, do ponto de vista da DE, focar a atenção sobre o Sujeito implica assumir, por um lado, a necessidade de explicar o sentido que o Sujeito atribui à escrita e ao ato de produzir textos, em diferentes contextos; com efeito, sabe-se, hoje, que o insucesso ou êxito escolar pode depender mais do sentido que os alunos atribuem às experiências escolares (ROCHEX, 1998; CANÁRIO, ALVES, ROLO, 2001) do que do diferencial cultural que os rotula ou das suas competências cognitivas. Por outro lado, a compreensão dos processos de escrita dos Sujeitos não se compadece com a descrição de operações cognitivas, mas estabelece pontes com as dimensões individuais e sociais da linguagem escrita com que o Sujeito contacta, o que nos transporta para a consideração da escrita como fenómeno que excede, em larga medida, a dimensão cognitiva do Sujeito e a escrita escolar.

Isto significa, portanto, admitir a possibilidade de o Sujeito manter experiências pessoais com a composição escrita que ultrapassam as escritas escolares e a suposição de que o conhecimento acerca dessas experiências escriturais extraescolares é suscetível de propiciar a compreensão do modo como podem ser mobilizados recursos de linguagem disponíveis e apr(e)endidos através dessas várias experiências de escrita livre (PENLOUP, 2006; CARDOSO, 2009).

A investigação em DE tem sido, assim, permeável a perspetivas cognitivas e sociocognitivas, sociais e psicossociais, ad(o)aptando e propondo vários modelos, seja para explicar a atividade de escrita, caminhando para um enfoque no Sujeito, destacando o afeto pela escrita e a forma como gere a influência do ambiente que o 
rodeia, seja para estabelecer princípios e orientações para o seu ensino (PEREIRA, ALEIXO, CARDOSO, GRAÇA, 2010).

Estas proposições, para lá de destronarem uma visão deficitária (da competência escritural) do Sujeito, conduzem a equacionar que as representações, embora fazendo parte da competência escritural, não são suficientes para abranger a história do Sujeito como escrevente, os usos que faz da escrita, os sentidos que lhe atribui e uma dimensão atitudinal face à escrita institucionalizada e noutros contextos extraescolares. Assim, consideramos, na linha de C. Barré-De Miniac (2008) e de M.-C. Penloup (2000), que a noção de relação com a escrita - segundo a definiu C. Barré-De Miniac (2000) - faz parte da competência escritural do Sujeito e inclui as representações, pelo que tem maior capacidade explicativa e heurística, donde decorre, também, uma maior operacionalidade didática. De facto, a possibilidade de atentar numa ou em várias das suas dimensões - investimento feito na escrita, opiniões e atitudes relacionadas com a escrita; conceções sobre a escrita e a sua aprendizagem e modos de verbalização sobre a escrita - será mais viável para a consecução de desenhos investigativos e mais consequente para a prática didática, no sentido de aprofundar a caracterização e o conhecimento sobre a relação com a escrita dos alunos, inferindo daí pistas de trabalho didático.

Podemos dizer, sumariamente, que o enfoque na relação com a escrita enfatiza e assenta sobre:

i. a singularidade do Sujeito e da sua competência escritural, ou seja, a forma pessoal e única, consciente ou inconsciente, como este reúne os vários elementos intrincados na sua competência escritural e se posiciona face ao ato de escrever, em geral, e à sua forma de viver a escrita, em particular;

ii. a "globalidade" da escrita, princípio defendido por B. Lahire (1993) e que remete para a importância de se atender à presença da escrita em vários contextos - escolares e extraescolares (pessoais, familiares, grupais, juvenis, associativos, sociais, profissionais, institucionais);

iii. a "leitura positiva"2 (CHARLOT, 1997; 2000) dos Sujeitos, no sentido de pretender descrever os vários contextos em que contactam com a escrita, as relações que são entretecidas em cada um. Esta descrição poderá levar, sobretudo, a avançar na descoberta de pistas e de saberes (PENLOUP, 2008) e de testagem de modos de abolir ruturas entre escritas.

2 "Praticar uma leitura positiva é prestar atenção também ao que as pessoas fazem, conseguem, têm e são, e não somente àquilo em que elas falham e às suas carências." (CHARLOT, 2000, p. 30). 
Parece ser pacífico que a noção de relação com a escrita é complexa, heterogénea e instável. Já não o é a forma como a relação com a escrita pode sofrer mudanças. Houve estudos que já demonstraram que os alunos, quando passam por "experiências (didáticas) novas" com a escrita, transformam a sua relação com a escrita (LAFONT-TERRANOVA, 2008); no caso dos professores, também já se provou, numa experiência de investigação, que a sua relação com um objeto de produção textual específico, enquanto objeto de ensino-aprendizagem, mudou graças à utilização reflexiva que foi feita de um novo dispositivo didático (sequência didática) que os professores consentiram introduzir e testar na sua prática (WIRTHNER, 2008). Isto significa que, nestas duas investigações referidas, como se apercebeu B. Schneuwly (2008), a relação com a escrita não deve ser concebida como explicans mas como explicandum, isto é, que a relação com a escrita, nestas experiências investigativas, não explica as práticas, mas, antes, deve ser explicada pelas práticas que nela intervieram, transformando-a. Por outro lado, pensando na noção de relação com a escrita, em geral, e não só no contexto das investigações que acabámos de referir, consideramos que as práticas, de professores e alunos, podem ser explicadas pela sua relação com a escrita, que mescla fatores vários como as ideias do Sujeito, a sua história como escrevente, modos de construção subjetiva. Portanto, a relação com a escrita é causa e consequência de práticas.

A ligação das práticas à relação com a escrita e vice-versa não é, contudo, unilateral nem mecânica. A questão está em saber se vale a pena atuar nas práticas para conduzir a mudanças na relação com a escrita, se vale a pena atuar na relação com a escrita, conduzindo a outras práticas do Sujeito. Podemos, assim, questionar: será o trabalho didático, focado em saberes e saberes-fazer, guiado por pressupostos validados de uma "nova pedagogia da escrita" (PEREIRA, 2008) (VS paradigma redacional) ${ }^{3}$, suscetível de induzir novas relações com a escrita? Ou haverá mais pertinência de analisar e trabalhar didaticamente o rapport, gerando verbalização e discussão sobre a própria relação com a escrita? Ou seja, não sabemos se haverá mais proficuidade de um tratamento didático indireto do rapport à l'écriture se de um tratamento direto. Pelo menos, não temos dúvida da pertinência desse tratamento didático nem da sua exequibilidade e também não temos dúvidas de que as práticas espontâneas do Sujeito e as práticas induzidas em dispositivos de ensino-aprendizagem, que proporcionem ao Sujeito elementos novos, alimentam a eterna (re) configuração da sua relação com a escrita.

3 Muito mais produtiva do que o designado paradigma redacional de ensino de escrita (REUTER, 1996; PEREIRA, 2000), ou antes, da ausência do seu ensino - a escrita como corolário de atividades, para o aluno mostrar que sabe, em que se avalia o que não se ensina - vide uma síntese em CARDOSO (2009). 
Pelo que já foi dito, depreende-se que a relação com a escrita se constrói na escola e fora da escola e é justamente para descobrir situações de dualidade escritural (BARRÉ-DE MINIAC, CROS, RUIZ, 1993) e autorizar a fusão de escritas e de saberes, sem a renúncia ao ser, que angaria relevo a abordagem de índole etnográfica e sociológica do repertório de práticas escriturais livres (PENLOUP, 1999) e de como podem interpelar e servir a DE.

Com efeito, "le sujet apprend en mobilisant ce qu'il croit, ce qu'il sait, ce qu'il est" (PENLOUP, 2006, p. 84) - por isso, estabelecer "un «état des lieux»du déjà-là" (BARRÉ-DE MINIAC, 2000, p. 112) dos aprendentes e dos modos de apropriação do saber escrever daí decorrentes é passível de fornecer pistas para o trabalho dos professores como agentes favorecedores da aprendizagem, em prol de uma efetiva escolarização em que o aluno se autorize a escrever, sentindo-se (Sujeito-) autor (ROCHA E VAL, 2003) do seu processo de aprendizagem e dos seus textos, sem inibições relativamente à linguagem escrita (GERALDI, 2002).

De instrumento de informação para o professor, as práticas extraescolares assumem um valor heurístico, pois permitem interrogar as práticas escolares de escrita, bem como o próprio docente e alunos, procurando descobrir/interrogar o seu "déjà-là" relativamente às dimensões que integram a sua relação complexa com a escrita, e os funcionamentos pedagógicos. A análise dos produtos escritos extraescolares adquire, igualmente, uma forma e um valor hermenêutico, ou compreensivo/interpretativo dos textos/discursos dos alunos e do Sujeito (aluno) nos seus textos/discursos, na perspetiva de leitura positiva das competências que o aluno já adquiriu e já começou a desenvolver e, portanto, de adaptação, aceitação, integração e reconhecimento do aluno como ele é e necessário reajustamento a essa diversidade de novos públicos da escola massificada. A "didatização" do extraescolar - isto é, a consideração das conclusões a que os estudos debruçados sobre o extraescolar têm chegado sob o ponto de vista da finalidade última da Didática: melhorar o processo de ensino-aprendizagem - não está, no entanto, isenta de algumas preocupações éticas, riscos e de algumas precauções que, a serem descurados, poderão gerar derivas aplicacionistas, paradoxos, entendimentos perversos e ações didáticas infrutíferas, como é o caso dos efeitos "antipedagógicos" da conceção abusiva e desajustada de "o aluno no centro" (REUTER, 2001) ${ }^{4}$.

\footnotetext{
4 Não desenvolveremos aqui este ponto, que nos mereceu noutro contexto mais reflexão e uma
} síntese dos contributos por nós conhecidos até à data (CARDOSO, 2009). 


\section{OFICINA DE ESCRITA: DE INSTRUMENTO DE APRENDIZAGEM A INSTRUMENTO DE INVESTIGAÇÃO DA RELAÇÃO COM A ESCRITA}

Partindo, então, da convicção de que é necessário conhecer e trabalhar, em contexto escolar, a relação do aluno/Sujeito com a escrita, extraescolar e escolar - seja pela abordagem indireta seja pela direta -, infere-se que é preciso construir ou adaptar instrumentos para esse efeito, como questionários, discussões coletivas, entrevistas, testemunhos, observação (REUTER, 1996; BARRÉ-DE MINIAC, 2000). Além destes, parece-nos que há outro dispositivo didático-investigativo suscetível de fazer emergir discursos que contribuam para a compreensão da relação com a escrita e para intervir na reconstrução dessa relação - a oficina de escrita e, sobretudo, como explicitaremos, a oficina sobre a escrita.

Assumindo o polimorfismo das oficinas de escrita (LAFONT-TERRANOVA, 1999), podemos dizer que uma grande parte pretende ser um espaço reparador da relação do Sujeito com a escrita (BARRÉ-DE MINIAC E POSLANIEC, 1999), contribuindo para reconciliar o Sujeito com a escrita, de que existem já alguns testemunhos (1999; SWOPE, 2006; OLIVEIRA, 2011).

Contudo, esta vertente transformadora da oficina de escrita dependerá, em larga medida, da própria relação com a escrita do professor/animador, razão por que o professor precisa de proceder a uma tomada de consciência séria da sua própria relação com a escrita para melhor poder entender e intervir na dos outros. Por esta razão, é legítimo supor que, se o (futuro) professor experimentar uma situação de oficina de escrita, será implicado num processo capaz de produzir mudanças profundas quer nas suas conceções de escrita quer, doravante, na forma como ensina a escrever. Esta dimensão formativa da oficina, para professores e futuros professores (de língua, mas não só), tem sido explorada em algumas experiências de investigação/formação (GARCIA-DEBANC, 1989; CORRÊA, 2001; LAFONTTERRANOVA, 2008), cujo principal objetivo é fazer da oficina um lugar facilitador da evolução da relação com a escrita de cada um. Porém, esta dimensão formativa deverá, na nossa ótica, ser dirigida não só aos professores e futuros professores, mas aos próprios alunos (CARDOSO, PEREIRA, 2008).

Se tivermos em conta a precaução que se impõe ao convocar a relação pessoal do Sujeito com a escrita, em contextos escolares e extraescolares, vislumbraremos a proficuidade de realizar oficinas, em quadros investigativos, em que os alunos têm a segurança da salvaguarda do seu anonimato e de as suas declarações e atitudes autênticas face à escrita não serem consideradas em contextos avaliativos. A oficina poderá, assim, revelar-se um instrumento de investigação ao serviço da didática da 
relação com a escrita, por consentir um contacto contínuo com os alunos no sentido de criar situações que os levem a verbalizar sobre a (sua) escrita. Devemos dar conta deste desvio do foco habitual deste dispositivo didático, referindo-nos, antes, a uma oficina sobre a escrita, de dimensão acentuadamente investigativa e reflexiva. Com efeito, o foco de uma oficina de escrita costuma ser o trabalho de produção escrita, ora mais associado ao prazer ora ao labor de fabrico dos textos; neste caso, o foco que vamos adotar, numa oficina sobre a escrita com alunos, é a reflexão sobre a própria escrita dos Sujeitos, em contextos diversificados, e sobre a escrita, de forma geral. Colocamos, ainda, a hipótese de que esta oficina sobre a escrita, por via da reflexão, da discussão e da verbalização acerca da relação com a escrita suscite o desejo de escrever e faça percecionar sentidos para a escrita que não tenham sido descobertos. Digamos que esta entrada na relação com a escrita dos Sujeitos poderá ser uma fase propedêutica de uma "nova pedagogia da escrita". No entanto, o percurso também poderá ser ao contrário: ser uma "nova pedagogia da escrita" a desencadear mudanças na relação com a escrita - convicção de que, aliás, partem as oficinas de escrita, dispositivo didático exemplificativo do trabalho sistemático que a complexidade da escrita exige.

A oficina sobre a escrita será, portanto, um dispositivo didático-investigativo, pois existe um vaivém entre a investigação e a ação didática: a investigação desencadeia temas de reflexão para a ação e a própria ação fornece pistas que densificam a investigação, ou seja, por um lado, desencadeia-se a aparição, manipulação de representações no discurso e, por outro, essas representações são usadas para o discurso, como instrumento estratégico, considerando as representações na sua instabilidade, fragilizando o seu conteúdo. A oficina centra-se na relação com a escrita - noção dinâmica e aberta -, que inclui os aspetos relativos ao Sujeito e ao meio sociocultural a que pertence e em que a Escrita existe e se assume ora na sua natureza pessoal (do Eu) ora relacional e social (para os outros), elo e expressão da relação do Sujeito consigo, com os outros, com o mundo. Por sua vez, e porque nos interessam as questões didáticas, consideramos a escrita escolar - obrigatória - e extraescolar - livre. Quer a segunda, privilegiadamente mais associada ao desenvolvimento identitário do Sujeito, quer a primeira, que se espera mais associada à construção da pessoa como Sujeito de saber, devem interagir e gerarse mutuamente, já que o Sujeito só consegue construir saber através da linguagem escrita se este fizer sentido pela ligação estreita que estabeleça com a sua identidade (BAUTIER E ROCHEX, 1998); por outro lado, a identidade pode adquirir mais consciência e domínio sobre si própria beneficiando de "formas escritas" mais consolidadas e amadurecidas. 
Dos elementos que considerámos, construímos o esquema abaixo que pretende ilustrar os conceitos que interagem numa abordagem (oficinal) da relação com a escrita, constituindo-se, por isso, num modelo concetual que cremos elucidativo das dinâmicas, interações e da incompletude da relação com a escrita. A relação com a escrita, dinâmica e aberta (como o círculo entrecortado pretende dar conta), gira, na oficina sobre a escrita, entre a Didática investigativa e a prática, como pretendemos ilustrar pelas setas bidirecionais. Esta relação com a escrita e o escrever é a relação de um Eu que (não) escreve para os Outros, com os Outros, num meio em que existem os Outros; é, portanto, dependente do caráter individual e sociocultural da escrita. Deste caráter duplo, sobressaem outras bipolaridades como a escrita obrigatória - escolar - e a escrita livre - extraescolar - bem como a função identitária, previsivelmente assumida em escritos extraescolares, e a função epistémica, desejavelmente construída em contextos institucionais escolares. Estas duas funções têm de se gerar mutuamente, sob pena de comprometer o escrito/a escrita de cada Sujeito, originando, in extremis, ou uma pretensa escrita de saber sem sentido ou uma pseudo escrita criativa/ "literária" inc(s)ipiente.

Figura 1. Modelo conceptual da oficina sobre a escrita.

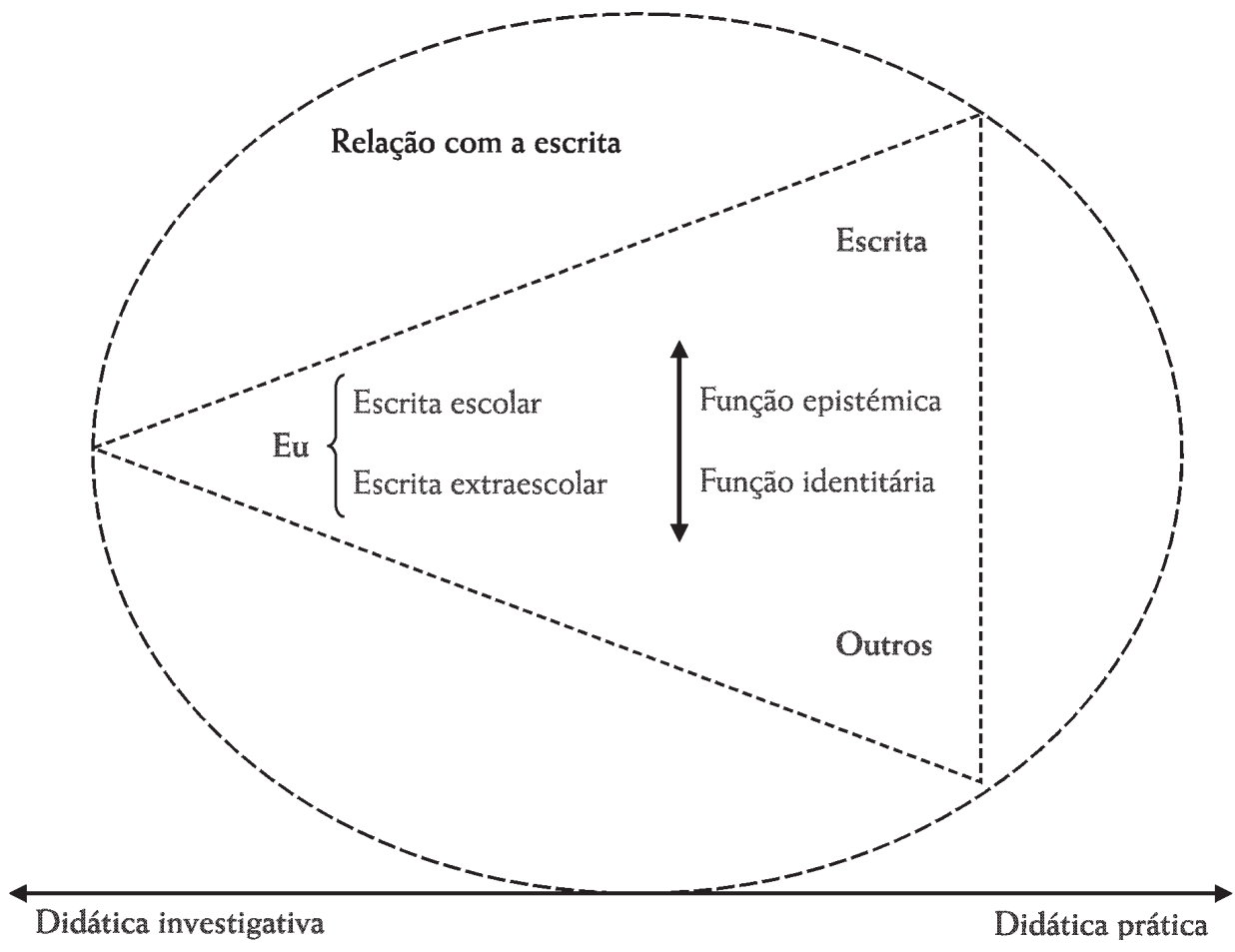




\section{DISPOSITIVO DE INVESTIGAÇÃO}

Assumindo que a relação com a escrita, enquanto objeto de estudo, exige olhares sobre diversas dimensões, devido à complexidade, à multiplicidade e à volubilidade que a caracterizam, então o nosso posicionamento metodológico só poderia ser híbrido. No contexto do nosso trabalho de Doutoramento (CARDOSO, 2009), pretendíamos saber que textos é que alunos do Ensino Básico 5 (EB) produziam fora da escola e na escola, porque em Portugal não havia estudos sobre a escrita livre da população estudantil desta faixa etária. Simultaneamente, intentávamos analisar e compreender a relação com a escrita - na escola e fora da escola - dos adolescentes, problematizando como é que este conhecimento pode interessar à intervenção didática, na promoção do desenvolvimento da competência escritural, visionando-o como potencial facilitador.

Articulámos, assim, metodologias quantitativas e qualitativas, adaptandoas a uma fase mais extensiva e a outra mais intensiva da investigação. Na fase extensiva, construímos e aplicámos o questionário "A Tua Escrita" em escolas do distrito de Aveiro. Recolhemos 226 questionários nos $6 .^{\circ}$ e $8 .^{\circ}$ anos do EB, idades compreendidas entre os 11-12 anos e os 13-14, respetivamente. Partimos, portanto, da hipótese de que a identidade dos alunos, enquanto escreventes, se constrói também fora da escola - contexto em que os alunos parecem escrever com regularidade e diversidade. Além disso, algumas experiências investigativas exploratórias anteriores também nos deram a entender que as práticas escolares de escrita poderiam estar a influenciar a visão que os alunos tinham da escrita. A fase extensiva caracterizou-se, assim, por um tratamento quantitativo de dados que nos permitiu traçar um retrato "orientador" de práticas de escrita escolares e extraescolares ${ }^{7}$; obtivemos, deste modo, um referencial para comparar com os resultados da outra fase.

No entanto, dados desta natureza seriam per se incapazes de facultar o aprofundamento da complexidade da relação do aluno/Sujeito com a escrita -

5 Em Portugal o EB é de nove anos, obrigatórios, divididos em 3 ciclos: primeiro ciclo (entrada na escola com 6 anos) - do $1 .^{\circ}$ ao $4 .{ }^{\circ}$ ano; $2 .^{\circ}$ ciclo $-5 .^{\circ}$ e $6 .^{\circ}$ anos; $3 .^{\circ}$ ciclo - do $7 .^{\circ}$ ao $9 .^{\circ}$ ano.

6 A construção deste instrumento apoiou-se no questionário "Écris-tu quand tu n'y es pas obligé(e)?" (PENLOUP, 1999) e em estudos-piloto que empreendemos bem como na nossa própria experiência escritural e enquanto docente. No quadro de um outro projeto coletivo de investigação, aplicámos recentemente um questionário com finalidades semelhantes, mas a uma amostra a nível nacional (tratamento de dados em curso).

7 Relacionando os dados com variáveis como género, idade, nacionalidade, estatuto sociocultural (indicadores: profissão e escolaridade das pessoas do agregado familiar), ano de escolaridade, nota mais habitual à disciplina de Português e n. ${ }^{\circ}$ de reprovações (CARDOSO, 2009). Contudo, neste texto, não é nosso objetivo focar estes aspetos. 
escolar e extraescolar - e, muito menos, de nos fazer aceder às dinâmicas de (re) construção dessa relação. Queríamos aprofundar sentidos atribuídos à escrita e perspetivar formas de atuação, razão por que concebemos e usámos instrumentos de pesquisa qualitativa que nos auxiliaram a sustentar um diálogo entre nós e os alunos participantes. Neste texto concentramo-nos, precisamente, nos resultados obtidos sobretudo a partir dos discursos orais e escritos dos alunos intervenientes na fase intensiva. De facto, estes discursos são lugar por excelência de manifestação de traços da sua relação com a escrita e, por isso, promissores quanto à possibilidade de a caracterizar e compreender.

Assim, na fase intensiva, empreendemos um estudo de caso, por permitir uma abordagem mais complexa, intensiva e indutiva. Trabalhámos com uma turma de $7 .^{\circ}$ ano, composta por 16 alunos, que uma escola do centro da cidade pôs à nossa disposição. Ocupávamos horas da aula de Português, oferecidas pela docente da disciplina que, nos dias em que estávamos com a turma, se ausentava da aula.

Realizámos também com estes alunos duas séries de entrevistas ${ }^{8}$, cujos discursos foram totalmente transcritos: a primeira, sobre a relação dos alunos com a escrita extraescolar e escolar e a segunda, sobre textos produzidos pelos sujeitos (previamente entregues) em ambiente escolar e extraescolar. A oficina sobre a escrita - "Eu, a Escrita e os Outros" -, em aula, desenvolvia-se paralelamente, segundo os pressupostos já delineados no ponto 3 , e decorreu durante quatro meses, em aulas agendadas com a professora de Português.

O suporte de escrita dos alunos, na oficina, foi o diário de bordo individual, usado quer para escrever durante cada sessão quer para fazer, no fim de cada uma, o seu balanço, seguindo orientações gerais, mas também específicas de cada modo de trabalho - permitindo, também, um registo mais introspetivo, pessoal e livre do Sujeito. No final de cada sessão, recolhíamos os diários dos alunos, a fim de lermos as suas escritas e de lhes escrever também - comentando, questionando, para aprofundar, clarificar, indagar razões, suscitar reflexões, incitar mais escritas... O diário era devolvido na sessão seguinte, para continuar a possibilitar a emergência de conceções acerca da escrita e o processo de inscrição e de (re)construção de relação com a escrita.

8 Cada uma com duração entre 45 minutos a duas horas. O modelo de entrevista adotado, no que respeita à estruturação e à diretividade, foi a entrevista semiestruturada, enquadrando-se, também, na definição de entrevistas em profundidade. A opção por este tipo de entrevista prendeu-se com o facto de não pretendermos nem uma conversa livre nem rigidamente orientada, mas que contivesse como referencial um conjunto de questões, flexível e adaptável às necessidades decorrentes do desenvolvimento das entrevistas. 
O desenvolvimento da oficina sobre a escrita obedeceu, por conseguinte, aos dados emergentes dos diários de bordo dos Sujeitos e das entrevistas e procurou contemplar três dimensões da escrita: a pessoal, a social e a cognitiva ou processual ${ }^{9}$. Neste artigo, não nos detemos sobre estas dimensões em especificidade, mas, depois de darmos algumas informações que foi possível apurar mais na fase extensiva, daremos enfoque à compreensão da relação com a escrita que foi possibilitada na fase intensiva do estudo, salientando os principais resultados suscetíveis de desencadear uma reflexão em prol das práticas de ensino da escrita e da já referida "nova pedagogia da escrita" que se impõe atualmente. As macrocategorias orientadoras da análise de conteúdo empreendida ${ }^{10}$ coincidem com as quatro dimensões da relação com a escrita já enunciadas. Analisámos separadamente os dados relativos aos contextos escolar e extraescolar, que motivaram, necessariamente, o surgimento de algumas subcategorias distintas. O quadro seguinte dá conta da estruturação seguida na análise (fase intensiva):

Quadro 1. Categorias e subcategorias de análise

\begin{tabular}{|c|c|c|c|}
\hline & & Escrita escolar & $\begin{array}{c}\text { Escrita } \\
\text { extraescolar }\end{array}$ \\
\hline $\begin{array}{l}\text { Dimensões da } \\
\text { relação com a } \\
\text { escrita }\end{array}$ & Categorias & Subcategorias & Subcategorias \\
\hline $\begin{array}{l}\text { Investimento } \\
\text { feito na escrita }\end{array}$ & Investimento & $\begin{array}{l}\text { Exercício (individual, grupo, } \\
\text { suporte, divulgação) } \\
\text { Português; Disciplinas } \\
\text { Tipo de escrita (escrita compositiva } \\
\text { imaginária e real; não compositiva; } \\
\text { associada a linguagem não verbal; } \\
\text { outra) } \\
\text { Heteroimagens }\end{array}$ & $\begin{array}{l}\text { Divulgação } \\
\text { Tipo de escrita } \\
\text { (escrita poética, } \\
\text { memorialista, } \\
\text { utilitária, } \\
\text { dramática/ } \\
\text { BD, reflexiva/ } \\
\text { intimista, } \\
\text { passatempo, } \\
\text { comunicacional, } \\
\text { outra) } \\
\text { Heteroimagens; } \\
\text { práticas de } \\
\text { outros } \\
\text { Locais; } \\
\text { suportes; temas }\end{array}$ \\
\hline
\end{tabular}

9 Para um maior aprofundamento sobre a descrição do modo de funcionamento do atelier, vide CARDOSO, PEREIRA, 2008.

10 Sobretudo com recurso ao software N-Vivo 7. 


\begin{tabular}{|c|c|c|}
\hline \multirow{3}{*}{$\begin{array}{l}\text { Opiniões } \\
\text { e atitudes } \\
\text { relacionadas } \\
\text { com a escrita }\end{array}$} & Atitudes & \\
\hline & Opiniões & $\begin{array}{l}\text { Valores positivos, negativos, neutros, mistos; funções; } \\
\text { sentimentos }\end{array}$ \\
\hline & Recordações & \\
\hline \multirow{3}{*}{$\begin{array}{l}\text { Conceções } \\
\text { sobre a } \\
\text { escrita e a sua } \\
\text { aprendizagem }\end{array}$} & Aprendizagem & $\begin{array}{l}\text { Conceções } \\
\text { Mediadores } \\
\text { Aquisições } \\
\text { Estratégias }\end{array}$ \\
\hline & Desempenho & $\begin{array}{l}\text { Autoimagem } \\
\text { Dificuldades - Tipologia (microestruturais; } \\
\text { macroestruturais), razões, mediadores, ações de } \\
\text { superação }\end{array}$ \\
\hline & Ensino & $\begin{array}{l}\text { Declarações } \\
\text { Opiniões } \\
\text { Avaliação } \\
\text { Conteúdos }\end{array}$ \\
\hline $\begin{array}{l}\text { Modos de } \\
\text { verbalização } \\
\text { sobre a escrita }\end{array}$ & $\begin{array}{l}\text { Modo de } \\
\text { verbalização }\end{array}$ & \\
\hline
\end{tabular}

\section{MODOS DE RELAÇÃO COM A ESCRITA}

A análise dos questionários recolhidos na fase extensiva do estudo permitiu confirmar que os alunos escrevem, fora dos muros da instituição escolar, quando não são obrigados a escrever. Traçámos, ainda, um retrato das práticas de escrita escolar, que demonstrou uma presença indiscutível e massiva da escrita não compositiva nas aulas bem como de algumas práticas escriturais constantes nos dois anos de escolaridade em causa. Ficou patente uma dualidade escritural nos Sujeitos inquiridos, que aderiram com entusiasmo ao questionário por, justamente, os transportar para uma dimensão da sua escrita raramente convocada na instituição escolar - daí a novidade que constituiu ${ }^{11}$.

$\mathrm{Na}$ fase intensiva, estes resultados foram confirmados e encontrámos zonas problemáticas ou representações-obstáculo. Foram estas representações que orientaram a formulação de atividades na oficina sobre a escrita. Por sua vez, a oficina, em maior escala, e, ainda, a segunda entrevista permitiram-nos detetar aquilo que denominámos de

11 Para um maior aprofundamento da análise do questionário da fase extensiva do estudo, vide CARDOSO, 2009. 
"indícios de mudança na relação com a escrita". Finalmente, concebemos três ideais-tipo de relação com a escrita, com base no nosso público-alvo, considerando o tempo global de investigação no terreno. Debruçar-nos-emos sobre cada um destes pontos per se.

\subsection{Representações-obstáculo associadas a um paradigma redacional de ensino da escrita}

A diversidade de relações com a escrita evidente nos Sujeitos não é incompatível com homologias que sobressaem pela frequência com que ocorrem:

- quanto ao entendimento mais generalizado e iminente de "escrita", coexistem vários tópicos definidores:

- a escrita é um meio de transcrever o imaginado, por isso é difícil para quem não tem imaginação;

- a escrita é um meio de transcrever o vivido, o acontecido - sendo, portanto, alimentada por aquilo que o Sujeito testemunhou e viveu, é "rápida e fácil",

- escrever é uma forma de memorizar e de estudar a "matéria";

- a escrita é um meio de transcrever a "matéria dada" e de dar prova de que se sabe

- a escrita é uma forma de passar/copiar apontamentos.

- quanto a critérios de avaliação de textos, o referencial de "bons textos" e de "boa escrita" repousa em modelos textuais identificados com uma (pseudo)literariedade, sustentada, sobretudo, por textos lidos;

- relativamente a condições para escrever bem, o acesso ao condão da literariedade dos textos é restrito àqueles que têm "jeito" para escrever, um certo "dom" para imaginar e criar "histórias" originais, bafejados por uma inspiração superior, raramente acessível em sala de aula.

Podemos considerar, assim, que os retratos da escrita escolar fornecidos pelos alunos configuram, essencialmente, 4 tipos de situações de escrita escolar:

1. A escrita para criar, com imaginação,

2. A escrita para contar, falando de si;

3. A escrita para provar que sabe, para ser avaliado;

4. A escrita para passar/copiar apontamentos. 
Excetuando a periodicidade regular do escrever-ser avaliado, escrever-criar e escrevercontar são menos frequentes do que escrever-passar e escrever-copiar, de que os alunos se cansam com frequência, mas a que também é reconhecida utilidade, por preparar para a memorização e para a prova de conhecimentos através da escrita. Escrever-passar e escrever-copiar são a representação mais imediata do ato de escrita, relatado como um gesto motor repetitivo nas aulas, associado a cansaço físico. Ora, o predomínio de uma escrita-reprodução na escola - com fins de registo do saber e que implica um esforço físico - em detrimento de uma escrita-produção - de (re) organização e construção de saber, que implica um esforço cognitivo e uma implicação afetiva e intelectual (BARRÉ-DE MINIAC, CROS, RUIZ, 1993) - fica bem evidente nos discursos do nosso público-alvo, comprometendo a experimentação da escrita como instrumento heurístico, cada vez mais necessária à medida que se progride no sistema de ensino.

Relativamente à qualidade dos textos escritos, no entender dos alunos, é extremamente dependente dos seguintes fatores, identificados nos seus discursos:

- Competência em oralidade;

- Performance e hábito assíduo de leitura;

- Domínio do assunto do texto a produzir,

- Avaliação do professor;

- Conjugar os requisitos de inspiração, imaginação, jeito/dom para escrever.

Parece, portanto, que falar bem e ler bastante e assiduamente conduzem, automaticamente, a escrever bem. A avaliação dos escritos também está sujeita aos gostos e às apreciações dos professores e ao domínio que o Sujeito tem do assunto do texto. A escrita é uma questão de ter jeito e imaginação ou não ter, embora, com a ajuda da inspiração que, por vezes, se sente, a tarefa escritural seja facilitada.

O sucesso escritural é muito mais dependente, creem os alunos, de fatores externos do que da possibilidade que está ao seu alcance de intervir e aperfeiçoar os seus textos. Assim, conseguimos identificar, na visão dos alunos, certas atitudes-chave para evitar os constrangimentos que apontam e para ser bem-sucedido na escrita - atitudes que estão, de resto, em íntima correlação com os fatores de sucesso enunciados: atenção, concentração, inspiração, calma, vontade ou disposição interior, o que se relaciona muito mais com a dimensão atitudinal e motivacional que liga o Sujeito à escrita do que com os saberes do funcionamento da língua e dos textos. 
As conceções predominantes sobre a escrita e a sua aprendizagem coartam a mobilização do Sujeito e deixam-no acomodado cognitiva e afetivamente. Na verdade, não abundam os testemunhos de experiências de escrita escolar que despertem, pelo menos afetivamente, a adesão dos alunos à escrita. No entanto, esta adesão, quando se nota, não terá sido conseguida fruto do trabalho com o processo de escrita nem fruto de um reconhecimento de sentido à especificidade escritural escolar. Pelo que percebemos, esta adesão ancora-se mais na identificação do aluno com algumas temáticas de escrita e menos num reconhecimento da lógica escritural; mais na oportunidade que é dada ao aluno de, aparentemente, poder ser "ele próprio" a escrever e menos no entendimento consensual de que a escrita mais "livre" pode ser um patamar que, pelo grau de identificação que comporta, tem capacidade para implicar o Sujeito por inteiro na experimentação de modos de aperfeiçoamento de um texto a que já se encontra afetivamente ligado.

O modo de verbalização dos alunos sobre a escrita acusa, precisamente, uma insegurança escritural revelada pela tensão a que quase sempre estão associadas as tarefas de escrita, pela incapacidade dos alunos de prever a avaliação e a classificação de um escrito em particular. Os alunos não demonstram, em geral, possuir métodos de trabalho com a língua escrita eficazes em circunstâncias diversas e suscetíveis de uma antecipação mais rigorosa da avaliação/classificação.

Através do modo como os alunos verbalizam as suas dificuldades, percebemos que vão pouco além da ortografia e da pontuação e que uns consideram "já saber escrever" e outros "ter ainda muito que aprender", o que contrasta com a ideia de que da escola primária se herdam os principais requisitos para escrever bem, que coexiste. Certamente, a convicção de que "já sei escrever" coaduna-se com a primeira imagem que os Sujeitos têm de si como escreventes, ou, antes, "escrivães" - já sabem escrever porque sabem copiar e passar bastantes apontamentos, passam a sua vida escolar a fazê-lo; sabem escrever porque conseguem executar o gesto físico de escrever, alinhar, de forma "direita", palavras nas páginas.

Ora, uma relação com a escrita marcada por representações-obstáculo como as que identificámos denuncia a inexperiência de uma escrita que se sujeite a processos de reformulação profunda e que elabore o pensamento e conhecimento e não os transcreva, somente, num ato cumulativo de "preenchimento de linhas".

Estes dados são suscetíveis, logicamente, de problematizar a responsabilidade que as habituais práticas pedagógicas do ensino da escrita, que se caracterizam pela aceitação de que os saberes escriturais são adquiridos por impregnação através do trabalho das outras competências (PEREIRA, 2000; 2004), estão a ter nas representações-obstáculo que os alunos apresentam. 


\subsection{Indícios de mudança na relação com a escrita}

$\mathrm{Na}$ oficina, pretendemos relativizar a centralidade do escrever-criar e do escrevercontar e dar exemplos de que há outros géneros de texto que existem na escola e noutros contextos. Deste modo, na sequência da participação neste projeto, os alunos apontam, no balanço que fazem, o facto de terem aprendido "muitas coisas sobre a escrita", nomeadamente que "a escrita é mais importante que eu julgava" (MJ'12), "é demasiado indispensável para o presente e para o futuro" (S). O confronto com os escritos e as declarações de outros sobre a escrita também permitiram aos alunos "descobrir como éa escrita para os outros, e entender que a escrita é muito importante. Nós agora pensamos que a escrita não éprecisa para nada, mas é uma das coisas fundamentais para termos um bom futuro" (SI). Também foi notório que os alunos começaram a tomar consciência do uso da escrita em diferentes contextos, reconhecendo a existência de múltiplos textos e finalidades do escrever, o que parece constituir um modo mais rigoroso de equacionar a escrita, que ultrapassa as designações generalistas e ambíguas de "composições" e de "textos normais", que surgiram inicialmente.

De acordo com a repetida frequência com que os alunos se referem à descoberta de que os erros ortográficos são, apenas, um entre muitos outros critérios de avaliação dos textos, percebemos que começaram a relativizar a importância deste aspeto que, afinal, era a "maior dificuldade" que referiam - ou, antes, a mais conhecida, porque a mais "objetiva" e óbvia nas correções.

Tendencialmente, também fomos notando uma linguagem comum com os alunos - efetivamente, uma menor associação imediata de escrita a caligrafia ou a cópia de apontamentos ia correspondendo ao facto de os pormos, mais vezes, a verbalizar sobre a forma como escreviam os seus textos. Isto significa que os alunos foram levados a diferenciar conscientemente a atividade de escrita-reprodução da de escrita-produção. Ora esta diferenciação consciente implicou, necessariamente, que o aluno se posicionasse mais como "autor" do que, simplesmente, como "escriba". A partir deste ponto de vista, os Sujeitos falaram abundantemente das suas escritas, alternando os contextos escolares e extraescolares, começaram a autorizar-se a transferir conhecimentos e saberes de uns contextos para os outros e a descobrir que têm a possibilidade de apurar as suas competências de escrita $a_{j}$ julgamos que esta afirmação de $\mathrm{H}$ é ilustrativa desta (mudança de) atitude - "Acho que comecei a perceber que a escrita não é nenbum bicho de sete cabeças".

12 As iniciais correspondem ao nome próprio dos alunos participantes. 


\subsection{Ideais-tipo: relação identitária e epistémica com a escrita}

Nas entrevistas com os Sujeitos, procurámos estabelecer comparações entre os produtos e os processos de escrita nos contextos escolar e extraescolar. Esta comparação permitiu-nos apreender a denominada dualidade escritural, não incompatível, porém, com alguns indícios de "pontes" entre o mundo da escrita obrigatória e o da escrita livre, e vice-versa, ainda que em diferentes graus de (re)conciliação.

Assim, agrupámos alguns tópicos definitórios da relação com a escrita na escola e fora da escola para melhor conseguir contrastar as diferenças encontradas entre os adolescentes e afinar, com mais rigor, esses graus de (re)conciliação entre dois mundos de escritas. Para isso, servimo-nos de um conceito já utilizado nas investigações da equipa ESCOL (CHARLOT, BAUTIER, ROCHEX, 1992) - o ideal-tipo. Digamos que a conceptualização dos modos de relação com a escrita (extra) escolar em ideais-tipo polariza o fenómeno de relação com a escrita, restituindo-lhe, ao mesmo tempo, uma lógica estruturadora e aglutinadora da sua complexidade. Assim, podemos conceber três ideais-tipo de relação com a escrita (extra) escolar que encontrámos na fase intensiva do nosso estudo:

\section{Ideal-tipo 1 - transitoriedade da escrita extraescolar e dualidade escritural} acentuada

São adolescentes que confessam a predileção pela escrita extraescolar, a vontade mais ou menos frequente para escrever, quando lhes apetece, o que lhes apetece, sobre o que quiserem. A liberdade destes escritos é usufruída, por exemplo, ao nível dos temas, dos suportes, do uso de "códigos" escriturais, dos registos de língua. Estes escritos fugazes raramente são conservados; são fragmentários e respondem, sobretudo, a impulsos para escrever motivados por sentimentos, pelo tempo de que os Sujeitos dispõem. São escritos importantes para o Sujeito, no momento em que optam por escrever, e, por isso, dotados de valor afetivo, porque cumprem a função que preside à escrita, mas a que a escola jamais reconheceria valor, segundo pensam. Na verdade, são negados elos entre o mundo desta escrita extraescolar e o da escrita escolar e não são notadas interinfluências destes dois contextos.

Ideal-tipo 2 - imprescindibilidade da escrita extraescolar e conciliação esporádica com a escrita escolar

A escrita extraescolar é praticada, sobretudo, por motivos pessoais, relacionados com o desenvolvimento identitário do aluno, e adquire importância no 
âmbito da história de vida do Sujeito, daí o desejo de conservar os escritos, como quem eterniza momentos dessa história individual. Escrever ajuda a organizar ideias, a pensar, a tomar decisões, a desabafar, a relaxar; a escrita assume-se, sobretudo, na sua vertente catártica, razão por que se considera impossível viver sem a escrita. Porém, na ótica dos Sujeitos, estes registos não interessam à escola, mas ao Sujeito e, eventualmente, a pessoas com quem privam. Além disso, são escritos com relativa liberdade e sem a preocupação de manter a correção expectável nos escritos escolares. Estas produções são um espelho do seu autor, na medida em que nelas se dão a conhecer como pessoas. Para a escola, consideram que só poderão retirar, dos textos livres, ideias a partir de experiências de vida ou o hábito de escrever e algum traquejo escritural/textual que daqui poderá advir. Sob o ponto de vista dos adolescentes que se integram neste ideal-tipo, os textos extraescolares são melhores em termos de desenvolvimento e de conteúdo; quanto aos textos escolares, são melhores em termos da "correção" na forma de expressão escrita.

\section{Ideal-tipo 3 - originalidade da escrita extraescolar e uma conciliação mais eficaz entre diferentes contextos de escrita}

Os adolescentes reconhecem a superioridade dos escritos extraescolares, mais interessantes por beneficiarem de melhores condições de realização (ambiente de concentração, "inspiração"; mediadores disponíveis para a apreciação valorativa dos textos; flexibilidade de tempo para escrever); são textos de que se recordam com facilidade, que guardam e, às vezes, mostram. Estes textos são "obras" conseguidas pelos seus autores, em que se sentiram realizados porque conseguiram obter um produto textual que lhes causa fruição e admiração. São escritos em que os adolescentes (se) investem, cuidando do seu aperfeiçoamento. Além de serem motivados por impulsos momentâneos, são movidos por um desejo de criação e de manifestação de originalidade. Para além do valor afetivo, estes textos são, seguramente, expressões de uma "tentation du littéraire" (PENLOUP, 2000), de uma escrita criativa com que os adolescentes se comprazem. Em meio escolar, segundo os alunos, a avaliação destes escritos dependeria de muitos fatores, normalmente externos ao texto - a opinião do professor, os interesses do professor -, sendo admitida, com reservas, a possibilidade de poderem ser apreciados pela instituição escolar. Destas práticas escriturais, os adolescentes consideram que podem extrair boas influências para a escrita escolar, sobretudo ao nível das ideias, das palavras (novas) e de um certo desenvolvimento na forma de produção textual, segundo 
declaram. O contributo da escola também não é negado, reconhecendo-se que a escrita escolar favorece uma melhor escrita extraescolar.

Aproximámos cada um dos sujeitos participantes na fase intensiva do estudo a cada um destes ideais-tipo (quadro 2), pese embora poucos sujeitos se identifiquem, exclusivamente, com apenas um ideal-tipo, o que denota, poderíamos dizer, uma relação com a escrita tecida de pluralidades e de variações. Apenas um rapaz e uma rapariga se identificam exclusivamente com o ideal-tipo 1; 4 meninas identificam-se, apenas, com o segundo ideal-tipo; finalmente, verificámos a identificação exclusiva de um rapaz (o melhor aluno) com o ideal-tipo 3 e que os restantes 9 adolescentes se identificam ou com o terceiro ideal-tipo e com o segundo (6) ou com o terceiro e o primeiro (3).

Quadro 2. Situação dos sujeitos de investigação em relação a cada ideal-tipo

\begin{tabular}{|c|c|c|c|}
\hline $\begin{array}{c}\text { Sujeitos de } \\
\text { investigação }\end{array}$ & $\begin{array}{c}\text { Ideal-tipo 1- } \\
\text { Transitoriedade } \\
\text { da escrita } \\
\text { extraescolar }\end{array}$ & $\begin{array}{c}\text { Ideal-tipo 2- } \\
\text { Imprescindibilidade } \\
\text { da escrita } \\
\text { extraescolar }\end{array}$ & $\begin{array}{c}\text { Ideal-tipo 3- } \\
\text { Originalidade } \\
\text { da escrita } \\
\text { extraescolar }\end{array}$ \\
\hline $\mathrm{AD}$ & & & \\
\hline $\mathrm{AL}$ & & & \\
\hline $\mathrm{AR}$ & & & \\
\hline $\mathrm{B}$ & & & \\
\hline $\mathrm{H}$ & & & \\
\hline $\mathrm{JA}$ & & & \\
\hline $\mathrm{JAN}$ & & & \\
\hline $\mathrm{M}$ & & & \\
\hline $\mathrm{MA}$ & & & \\
\hline $\mathrm{MJ}$ & & & \\
\hline $\mathrm{R}$ & & & \\
\hline $\mathrm{RT}$ & & & \\
\hline $\mathrm{S}$ & & & \\
\hline $\mathrm{SI}$ & & & \\
\hline $\mathrm{SO}$ & & & \\
\hline $\mathrm{V}$ & & & \\
\hline
\end{tabular}




\section{CONSIDERAÇÕES FINAIS}

Constatámos que a escrita extraescolar não é (tão) marcada por insegurança porquanto, obviamente, não é objeto de classificação e atinge as finalidades a que o aluno se propõe quando toma a decisão de escrever: escreve para passar o tempo, para se distrair, para relaxar, para brincar com as palavras, para contar histórias originais, para desabafar, para se preparar para falar, para se exprimir, para comunicar, etc... - a escrita cumpre sempre a sua função. É indiscutível a ligação da escrita - extraescolar - à vida do Sujeito, pelo que estaremos em condições de afirmar que existe, fora da escola, uma relação identitária com a escrita, que autoriza o escrever, em virtude do reconhecimento de um saber escrever útil, importante, convocado frequentemente. Nos Sujeitos do ideal-tipo 3, também existe, embora num grau diminuto, uma certa relação epistémica com a escrita, na medida em que a escrita é apreciada e praticada pelo gozo que a própria operação de escrever dá, pela busca de um produto escritural único e pela reflexividade que guia essa busca - ato reflexivo muito limitado, no entanto, a alguma intuição e àquilo que os alunos designam por "inspiração" e não alimentado por conhecimentos que se solidificam neste processo de "busca".

Em contrapartida, na escola, a reflexividade que alimenta um desenvolvimento epistémico escritural raras vezes se pôde pressentir por entre relatos de escritas escolares feitas à pressa, para entregar. Percebemos que os Sujeitos se desligam identitariamente da atividade escritural escolar, o que significa que o sentido da escrita escolar ficou comprometido - caminho aberto para a "produção", afinal, dos "excluídos da escrita escolar". A questão está em não continuar a ignorar que os alunos nutrem, com a escrita, uma relação identitária e que a escola é uma instituição privilegiada para ajudar a desenvolver, nos alunos, e a partir dessa relação identitária, uma relação epistémica com o saber escrever, que ajude o aluno a passar de uma escrita que só tem valor para si para uma escrita que tem valor por si, que é trabalhada e que passa a ter, portanto, um valor mais "objetivo", que serve para aprender, para elaborar, para se construir.

O problema, como dizia E. Bautier (1998), é continuar a incompatibilizar estes tipos de escrita, a que nós agora chamaremos de manifestações de uma relação identitária ou de uma relação epistémica com a escrita, que não são e não podem ser incompatíveis. Contrariamente a uma suposição presente na classe docente (PEREIRA, 2003) e, talvez, de quase senso comum, os alunos não parecem precisar que a escola lhes incuta o gosto pela escrita; verificámos que os alunos, Sujeitos participantes, (já) o têm, de modos diversos. O que a escola precisa é de auxiliar o 
aluno a evoluir de uma escrita de que se servem para referenciar a vida para uma escrita que os ajude a modalizar a vida, a mudá-la e a transformá-la.

Estamos a assumir, portanto, que não é possível uma construção de uma relação epistémica com a escrita se ela renunciar à relação identitária que já existe; não é possível a inclusão escolar através da escrita se a escrita escolar excluir, à partida, os modos identitários de o aluno escrever: se isso continuar a acontecer, continuaremos a ter alunos que, a escrever, têm sempre duas identidades, uma positiva e negativa, que são paralelas e, portanto, são polos que não encontram conciliações. O que estamos a advogar é que a escola favoreça uma relação com a escrita - dando, portanto, "instruction that values the cultural identities and linguistic resources they bring into the classroom so they can develop powerful discourses that allow them to become contributors of knowledge in their own communities and in the larger society" (BALL, ELLIS, 2007, p. 511). Dessa forma, os alunos não se sentem "outros" quando aí escrevem, mas sentem que são o mesmo autor, o mesmo Sujeito que (se) investe em contexto extraescolar e que, quer na escola quer fora, encontra razões (diferentes) para escrever e para continuar a aprender a escrever. $\mathrm{O}$ que importa, afinal, é que os alunos possam ser Sujeitos das suas escritas, possam ser "Sujeitos" a escrever e não, apenas, alunos - resignados, inconformados, inseguros ou a desempenhar o seu ofício de alunos, só pelo cumprimento mais ou menos sacrificial de uma obrigação ou por respeito e simpatia pelo professor.

\section{REFERÊNCIAS BIBLIOGRÁFICAS}

(1999). The freedom writers diary - Their story, their words: How a Teacher and 150 Teens used writing to change themselves and the world around them. New York: Broadway Books.

ADAM, J.-M. (2001). Les textes types et prototypes: récit, description, argumentation, explication et dialogue. Paris: Nathan.

ALVES, R.A. (2008). A mente enquanto escreve. A automatização da execução motora na composição escrita. Tese de Doutoramento em Psicologia. Faculdade de Psicologia e de Ciências da Educação, Universidade do Porto, Porto.

AMOR, E. (2004). LITTERA - escrita, reescrita, avaliação - um projecto integrado de ensino e aprendizagem do Português: para a construção de uma alternativa viável. Lisboa: Fundação Calouste Gulbenkian. Serviço de Educação e Bolsas.

BALL, A.F.; ELLIS, P. (2007). Identity and the Writing of Culturally and Linguistically Diverse Students. In: Bazerman, C. (ed.), Handbook of Research on Writing: History, Society, School, Individual, Text. Erlbaum: Routledge, pp. 499-511.

BARBEIRO, L.F. (1999). Os alunos e a expressão escrita. Consciência metalinguística e expressão escrita. Lisboa: Fundação Calouste Gulbenkian. Serviço de Educação. 
BARBEIRO, L. F.; PEREIRA, L.Á. (2008). As dimensões do processo e do contexto no ensino da escrita. Intercompreensão $n .^{\circ}$ 14, pp. 111-127.

BARRÉ-DE MINIAC, C. (2000). Le rapport à l'écriture: aspects théoriques et didactiques. Villeneuve d'Ascq (Nord): Presses Universitaires du Septentrion.

BARRÉ-DE MINIAC, C. (2008). Le rapport à l'écriture: une notion à valeur euristique. Diptyque n. ${ }^{\circ} 12$, pp. 11-23.

BARRÉ-DE MINIAC, C.; CROS, F.; RUIZ, J. (1993). Les collégiens et l'écriture: des attentes familiales aux exigences scolaires. Paris: ESF Editeur.

BARRÉ-DE MINIAC, C.; POSLANIEC, C. (1999). Écrire en atelier: Observation, analyse, interprétation de quatre ateliers d'écriture. Documents et travaux de recherche en éducation. Lyon: INRP.

BAUTIER, E. (1998). Je ou Moi: apprentissage ou expression? Cabiers pédagogiques $n .^{\circ} 363, p p$. 12-14.

BAUTIER, E. (2008). Ambitions et paradoxes des pratiques langagières scolaires : constructions au quotidien des inégalités sociales d'apprentissage. In: Actes $d u$ colloque "Ce que l'école fait aux individus». CENS \& CREN.

BAUTIER, E.; BUCHETON, D. (1995). L'écriture: qu'est-ce qui s'enseigne, qu'est-ce qui s'apprend, qu'est-ce qui est déjà là? Français Aujourd'bui $n .^{0} 111$.

BAUTIER, E.; ROCHEX, J.-Y. (1998). L'expérience scolaire des nouveaux lycéens. Paris: Armand Colin.

BRONCKART, J.-P. (2005). Les différentes facettes de l'interactionnisme socio-discursif. Calidoscópio n. ${ }^{\circ}$ 3, pp. 149-159.

BRONCKART, J.-P. (2007). Desarrollo del lenguaje y didáctica de las lenguas. Buenos Aires: Miño y Dávila.

CANÁRIO, R.; ALVES, N.; ROLO, C. (2001). Escola e exclusão social. Para uma análise crítica da política TEIP. Lisboa: Instituto de Inovação Educacional.

CARDOSO, I. (2009). A relação com a escrita extra-escolar e escolar. Um estudo no Ensino Básico. Tese de Doutoramento em Didática. Departamento de Didáctica e Tecnologia Educativa, Universidade de Aveiro, Aveiro.

CARDOSO, I.; PEREIRA, L. Á. (2008). Les potentialités didactiques d'un atelier d'écriture réalisé pour l'approfondissement du rapport du sujet à l'écriture. In: Céleste, B. (ed.), Écritures sans frontières. Suresnes: Éditions de l'Institut National Supérieur de Formation et de Recherche pour l'Éducation des Jeunes Handicapés et les Enseignements Adaptés (INS HEA), pp. 177-186.

CARVALHO, J. A. B. (1999). O Ensino da Escrita - da teoria às práticas pedagógicas. Braga: C.E.E.P. - Universidade do Minho.

CARVALHO, J. A. B. (2013). A transição para o Ensino Superior - novos contextos, novas práticas de literacia. In: Pereira, L.Á.; Cardoso, I. (eds.), Reflexão sobre a escrita. O ensino de diferentes géneros de textos. Aveiro: UA Editora, pp. 225-239. 
CHANQUOY, L. (2009). Revision processes. In: Beard, R.; Myhill, D.; Riley, J.; Nystrand, M. (eds.), The SAGE Handbook of Writing Development. London: SAGE Publications Ltd, pp. $80-98$.

CHARLOT, B. (1997). Du rapport au savoir. Eléments pour une théorie. Paris: Anthropos.

CHARLOT, B. (2000). Da relação com o saber. Elementos para uma teoria. Porto Alegre: Artmed Editora, 1997.

CHARLOT, B.; BAUTIER, E.; ROCHEX, J.-Y. (1992). École et savoir dans les banlieues... et ailleurs. Paris: Armand Colin.

CHARTRAND, S.-G. (2006). Un difficile rapport à l'écrit. Québec français n. ${ }^{\circ}$ 40, pp. 82-84.

CORRÊA, M. C. (2001). Escrita: esse obscuro objeto de desejo. Tese de doutorado em Aquisição da Língua Materna. Porto Alegre, PPGL/UFRGS.

CORTESÃO, M. M. C. R. (2012). O ensino de Poesia com Quadro Interativo. Um estudo no 1. ${ }^{\circ}$ Ciclo do Ensino Básico. Tese de Mestrado em Didática, ramo de Tecnologia. Departamento de Educação, Universidade de Aveiro, Aveiro.

COUTINHO, M.A. (2003). Texto(s) e competência textual. Lisboa: FCG/FCT.

COUTINHO, M. A. (2007). Géneros textuais. Calidoscópio n. ${ }^{\circ}$ 3, pp. 20-50.

GARCIA-DEBANC, C. (1989). De l'usage d'ateliers d'écriture en formation d'enseignants de français. Pratiques $n .^{\circ}$ 61, pp. 29-56.

GERALDI, J. W. (2002). Culturas orais e língua escrita: três retratos três por quatro. Educação, Sociedade e Culturas n. ${ }^{0}$ 18, pp. 105-121.

GOODY, J. (1988). Domesticação do pensamento selvagem. Lisboa: Editorial Presença, 1979.

GRAÇA, L. (2010). O papel das ferramentas didácticas nas práticas docentes de escrita. A análise do objecto ensinado numa sequência didáctica do texto de opinião no Ensino Básico. Tese de Doutoramento em Didática. Departamento de Didáctica e Tecnologia Educativa, Universidade de Aveiro, Aveiro.

HAYES, J. R. (1996). A new framework for understanding cognition and affect in writing. In: Levy, C.M.; Ransdell, S. (eds.), The science of writing theories, methods, individual differences, and applications. Mahwah (NJ): Lawrence Erlbaum Associates, pp. 1-27.

LAFONT-TERRANOVA, J. (1999). Pour une etbnolinguistique des ateliers d'écriture. Analyse de pratiques sur plusieurs terrains. Vol. I e II. Lille: ANRT Diffusion - Atelier nationale de reproduction des thèses.

LAFONT-TERRANOVA, J. (2008). Travailler conjointement l'investissement de l'écriture et les conceptions de l'écriture du sujet-écrivant. Diptyque $n .{ }^{0} 12$, pp. 25-42.

LAHIRE, B. (1993). Culture écrite et inégalités scolaires. Sociologie de "l'échec scolaire" à l'école primaire. Lyon: Presses Universitaires de Lyon.

LAHIRE, B. (2008). La raison scolaire. Ecole et pratiques d'écriture, entre savoir et pouvoir. Rennes: Presses Universitaires de Rennes.

OLIVEIRA, R. M. (2011). Escritas de vida, bistórias da escola. Na Roda Gigante. Porto: Cordão de Leitura. 
PENLOUP, M.-C. (1999). L'écriture extrascolaire des collégiens: des constats aux perspectives didactiques. Paris: ESF.

PENLOUP, M.-C. (2000). La tentation du littéraire: essai sur le rapport à l'écriture littéraire du scripteur «ordinaire». Paris: Didier.

PENLOUP, M.-C. (2006). Vers une didactique de l'écriture centrée sur l'apprenant et ses pratiques. In: Lafont-Terranova, J.; Colin, D. (eds.), Didactique de l'écrit. La construction des savoirs et le sujet écrivant. Actes de la journée d'études du 13 mai 2005. Namur: Presses Universitaires de Namur, pp. 81-104.

PENLOUP, M.-C. (2008). Les connaissances ignorées: approche pluridisciplinaire de ce que savent les élèves. Paris: INRP.

PEREIRA, L. Á. (2000). Escrever em português. Didácticas e práticas. Porto: Edições Asa.

PEREIRA, L. Á. (2001a). A formação de professores para o ensino da escrita. Inês Sim-Sim (org.). A formação para o Ensino da Língua Portuguesa na Educação Pré-Escolar e no $1^{\circ}$ Ciclo do Ensino Básico. Cadernos de Formação de Professores $n^{\circ}{ }^{\circ}$ 2, pp. 35-49.

PEREIRA, L. Á. (2001b). Os excluídos da Escrita Escolar. Outras razões para o João(zinho) (não) saber escrever. Educação, Sociedade e Culturas n. ${ }^{0}$ 15, pp. 99-115.

PEREIRA, L. Á. (2003). A produção escrita tal como se pensa-alguns dados de um inquérito. In: Mello, C.; Silva, A.; Lourenço, C.M.; Oliveira, L.; Araújo e Sá, M.H. (Eds.), Didáctica das Línguas e Literaturas em Portugal: contextos de emergência, condições de existência e modos de desenvolvimento, Actas do I Encontro Nacional da SPDLL. Coimbra, Faculdade de Letras da Universidade de Coimbra: Pé de Página Editores, pp. 313-320.

PEREIRA, L. Á. (2004). Des discours sur les pratiques aux pratiques d'enseignement. In: Barré-De Miniac, C.; Brissaud, C.; Rispail, M. (eds.), La littéracie: conceptions théoriques et pratiques d'enseignement de la lecture-écriture. Paris: L'Harmattan, pp. 319-333.

PEREIRA, L. Á. (2008). Escrever com as crianças - como fazer bons leitores e escritores: para crianças dos o aos 12 anos. Porto: Porto Editora.

PEREIRA, L. Á.; ALEIXO, C.; CARDOSO, I.; GRAÇA, L. (2010). The teaching and learning of writing in Portugal: The case of a research group. In: Bazerman, C.; Krut, R.; Lunsford, K.; McLeod, S.; Null, S.; Rogers, P.M.; Stansell, A. (eds.), Traditions of Writing Research. Oxford, UK: Routledge, pp. 58-70.

PEREIRA, L. Á.; CARDOSO, I. (2011). Ensinar a escrever com os Novos Programas de Português: 2. Ciclo do Ensino Básico. Porto: ASA.

PEREIRA, L. Á.; CARDOSO, I. (2013). A Sequência de ensino como dispositivo didático para a aprendizagem da escrita num contexto de formação de professores. In: Pereira, L. Á; Cardoso, I. (Coord.), Reflexão sobre a escrita. O ensino de diferentes géneros de textos). Aveiro: UA Editora, pp. 33-65.

PEREIRA, L. Á.; CARDOSO, I. (2010). Os textos de reflexão (livre) em contexto de formação de professores de escrita: Que género? Que mundos? Que desafios? In: Andrade, A. I.; Pinho, A.S. (eds.), Linguas e educação: práticas e percursos de trabalbo colaborativo. Perspectivas a partir de um projecto. Aveiro: Universidade de Aveiro, pp. 133-156. 
PEREIRA, L. Á.; CARDOSO, I. (Coord.). (2013). Atividades para o ensino da língua: Produção escrita. Protextos. Cadernos PNEP 3. Aveiro: UA Editora.

PEREIRA, L. Á.; CARDOSO, I.; GRAÇA, L. (2009). For a definition of the teaching/ learning of writing in L1: Research and action. L1 - Educational Studies in Language and Literature n. $^{\circ}$ 9, pp. 87-123.

PEREIRA, L. Á.; GRAÇA, L. (2008). Da conceptualização do contexto de produção e da sua produtividade na didáctica da escrita. In: Guimarães, A. M. d. M.; Machado, A. R.; Coutinho, A. (eds.), O Interacionismo Sociodiscursivo - Questões Epistemológicas e Metodológicas. Campinas: Mercado de Letras, pp. 177-189.

PEREIRA, S.C.F. (2007). Efeitos da sequência didáctica em textos escritos no $1^{\circ}$ Ciclo do Ensino Básico - O Relato. Dissertação de Mestrado em Didática. Departamento de Didáctica e Tecnologia Educativa, Universidade de Aveiro, Aveiro.

PINHO, A.D.S.D. (2008). Organização do texto argumentativo escrito em ambiente de b-learning. Tese de Doutoramento em Didática. Departamento de Didáctica e Tecnologia Educativa, Universidade de Aveiro, Aveiro.

RAYOU, P. (2000). L'enfant au centre. Un lieu «pédagogiquement» correct. In: Derouet, J.-L. (ed.), L'école dans plusieurs mondes. Bruxelles: De Boeck Université.

REUTER, Y. (1996). Enseigner et apprendre à écrire. Construire une didactique de l'écriture. Paris: Esf.

REUTER, Y. (2001). La «prise en compte» des pratiques extrascolaires de lecture et d'écriture: problèmes et enjeux. Repères. Pratiques extrascolaires de lecture et écriture des élèves $n^{\circ}{ }^{\circ} 23$, pp. 9-31.

ROCHA, G.; VAL, M. G. C. (2003). Reflexões sobre práticas escolares de produção de texto: o sujeitoautor. Belo Horizonte: Autêntica.

ROCHEX, J.-Y. (1998). Le sens de l'expérience scolaire: entre activité et subjectivité. Paris: PUF.

RODRIGUES, L. C. S. (2010). Dificuldades de Síntese na Escrita de Alunos do Ensino Superior Politécnico. Tese de Doutoramento em Didática. Departamento de Educação, Universidade de Aveiro, Aveiro.

ROSÁRIO, E. M .C. D. (2010). Aprendizagem da escrita através da web 2.0 - Um estudo com alunos do $3{ }^{\circ}$ ciclo do Ensino Básico. Dissertação de Mestrado em Multimédia em Educação. Departamento de Educação, Universidade de Aveiro, Aveiro.

SCHNEUWLY, B.; DOLZ, J. (2004). Gêneros orais e escritos na escola, trad. Roxane Rojo, Glaís Sales Cordeiro. Campinas: Editora Mercado de Letras, 2001.

SWOPE, S. (2006). Eu sou um lápis: um professor, os seus alunos e o seu mundo de bistórias, trad. Lucília Filipe. Lisboa: Sinais de fogo, 2004.

WIRTHNER, M. (2008). L'appréhension du rapport à l'écrit par le dispositif didactique. Diptyque n. ${ }^{\circ} 12$, pp. 87-105.

Recebido: 08/08/2014

Aceito: 18/04/2015 
